\title{
PERAN DESA ADAT DALAM TATA KELOLA LEMBAGA PERKREDITAN (LPD) DI BALI
}

\author{
Mia Hadiati ${ }^{1}$, Lis Julianti ${ }^{2}$, Moody R Syailendra ${ }^{3}$, Luthfi Marfungah ${ }^{4}$, Anggraeni Sari \\ Gunawan $^{5}$
}

${ }^{1}$ Fakultas Hukum, Universitas Tarumanagara

Email:miah@fh.untar.ac.id

${ }^{2}$ Fakultas Hukum, Universitas Tarumanagara

Email: julianti.lis@gmail.com

${ }^{3}$ Fakultas Hukum, Universitas Tarumanagara

Email: moodys@fh.untar.ac.id

${ }^{4}$ Program Doktor Fakultas Hukum, Universitas Brawijaya

Email: luthfimarfungah10@gmail.com

${ }^{5}$ Program Sarjana Fakultas Hukum, Universitas Tarumanagara

Email: anggraeni.205190143@stu.untar.ac.id

\begin{abstract}
LPD as one of the MicroFinance Institutions is very rapidly growing in Bali Province. LPD is said to be the business center of the informal sector. The existence of LPD as a credit institution in the village has been recognized based on customary law. In 2020 LPD in Bali amounted to about 1,433 LPD from a total of 1,485 Indigenous Villages in Bali which more served loans for villagers for various purposes. Therefore, in the management of LPD must be managed properly, correctly, transparency so that there is no misuse of LPD in its management and designation. The research method used in this research is normative-empirical legal research. This research is a blend of normative legal research and empirical legal research. Normative legal research is legal research that uses secondary data, while empirical legal research is legal research that uses primary data. Based on the results of this pre-study can be concluded the occurrence of criminal acts of corruption committed both the Board and lpd managers cause disputes. Disputes conducted by lpd managers and managers cause conflicts of interest either between the manager with customary karma or between managers and managers both in the duties and functions of their authority. Disputes over customary issues in the Village within the scope of LPD either indicated that cause village losses or violations of applicable laws and regulations are often resolved through national law compared to customary law that applies in an LPD area.
\end{abstract}

Keywords: Credit board, dispute, laws and regulations

\begin{abstract}
ABSTRAK
LPD sebagai salah satu Lembaga Keuangan Mikro sangatlah berkembang pesat di Provinsi Bali. LPD dikatakan sebagai pusat usaha sektor informal. Eksistensi LPD sebagai lembaga perkreditan di desa telah diakui keberadaannya berdasarkan hukum adat. Tahun 2020 LPD di Bali berjumlah sekitar 1.433 LPD dari total 1.485 Desa Adat di Bali yang lebih banyak melayani pinjaman bagi masyarakat desa untuk berbagai keperluan. Oleh karena itu didalam pengurusan LPD haruslah dikelola dengan baik, benar, transparansi agar tidak terjadi penyalahgunaan LPD di dalam pengelolaan dan peruntukannya. Metode penelitian yang digunakan dalam penelitian ini adalah penelitian hukum normatif-empiris. Penelitian ini merupakan perpaduan antara penelitian hukum normatif dan penelitian hukum empiris. Penelitian hukum normatif adalah penelitian hukum yang menggunakan data sekunder, sedangkan penelitian hukum empiris adalah penelitian hukum yang menggunakan data primer. Berdasarkan hasil pra penelitian ini dapat disimpulkan terjadinya tindak pidana korupsi yang dilakukan baik itu Pengurus dan pengelola LPD menimbulkan sengketa. Sengketa yang dilakukan oleh Pengurus dan pengelola LPD menimbulkan konflik kepentingan baik antara pengurus dengan karma adat atau antar pengurus dan pengelola baik dalam tugas dan fungsi kewenangannya. Sengketa permasalahan adat di Desa dalam ruang lingkup LPD baik itu terindikasi yang menimbulkan kerugian desa ataupun pelanggaran Peraturan Perundang Undangan yang berlaku seringkali sengketa tersebut diselesaikan melalui hukum Nasional dibandingkan dengan hukum adat yang berlaku di suatu wilayah LPD.
\end{abstract}

Kata Kunci: Lembaga perkreditan, sengketa, peraturan perundang-undangan 


\section{PENDAHULUAN \\ Latar Belakang}

Bali sebagai salah satu pulau yang terkenal dengan budayanya yang unik serta perkembangan pariwisatanya yang begitu pesat memberikan banyak ruang kepada masyarakat Bali khususnya untuk melakukan berbagai aktivitas ekonomi. Aktivitas tersebut memiliki potensi untuk meningkatkan kesejahteraan masyarakat, Pemerintah Provinsi Bali, serta pelaku-pelaku usaha di bidang jasa pariwisata. Pembangunan pariwisata di Bali bersumber dari kreativitas yang dimiliki oleh masyarakat lokal yang difasilitasi oleh Pemerintah. Oleh karena itu, upaya untuk terus melestarikan kearifan lokal di Bali semakin ditingkatkan untuk membangun kegiatan pariwisata di Bali.

Upaya yang dilakukan untuk tetap mempertahankan eksistensi kearifan lokal di Bali tidak terlepas dari ketersediaan sumber daya alam yang mendukung dan partisipasi sumber daya manusia yang ada di Bali untuk membangun dan mengembangkan budaya Bali melalui lembaga-lembaga Adat yang ada seperti Desa Adat, yang nantinya membantu mempromosikan daya tarik wisata di masing-masing daerah yang ada di Bali. Peraturan Daerah Provinsi Bali Nomor 4 Tahun 2019 tentang Desa Adat di Bali pada Pasal 1 ayat 8 mengatur bahwa Desa Adat adalah kesatuan masyarakat hukum adat di Bali yang memiliki wilayah, kedudukan, susunan asli, hak-hak tradisional, harta kekayaan sendiri, tradisi, tata krama pergaulan hidup masyarakat secara turun temurun dalam ikatan tempat suci (kahyangan tiga atau kahyangan desa), tugas dan kewenangan serta hak mengatur dan mengurus rumah tangganya sendiri.

Tujuan dibentuknya Desa Adat di Bali adalah untuk memberikan pengakuan dan penghormatan atas kedudukan dan peran Desa Adat dengan berbagai keberagaman budayanya, selain itu salah satu tujuan lainnya adalah untuk mewujudkan sistem perekonomian adat yang tangguh dan berdikari sebagai upaya untuk memperkuat sistem perekonomian nasional. Upaya untuk mewujudkan salah satu tujuan tersebut dalam rangka meningkatkan kesejahteraan masyarakat desa maka didirikanlah Lembaga Perkreditan Desa (LPD). LPD awalnya dibentuk berkat buah pikiran dari Gubernur Bali, prof. Ida Bagus Mantra. Gagasan mendirikan LPD diilhami karena telah melihat kesuksesan Lumbung Pitih Nagari (LPN) yang merupakan lembaga simpan pinjam masyarakat adat yang berada di Padang Sumatera Barat. Melihat dengan adanya konsep seeka dan desa adat yang telah tumbuh sejak lama di Bali, kemudian Gubernur Bali saat itu meluncurkan Lembaga Perkreditan Desa (LPD) dengan tujuan agar LPD dapat membantu desa adat dan karma desa dalam pembangunan adat, budaya dan agama di Bali. Sehingga pada saat itu dikeluarkannya Putusan Gubernur Kepala Daerah Tingkat I Bali Nomor 972 Tahun 1984 tertanggal 1 November 1984 tentang Pendirian Lembaga Perkreditan Desa (LPD) Bali. LPD tumbuh dengan kerangka yang sangat kuat di kehidupan masyarakat adat Bali, sehingga lembaga ini menerapkan aturan serta norma yang telah diyakini bersama yang disebut awig-awig.

LPD sebagai salah satu Lembaga Keuangan Mikro yang berkembang pesat di Provinsi Bali sebagai pusat usaha sektor informal, telah berdiri sejak 1988 berdasarkan Peraturan Daerah Provinsi Daerah Tingkat I Bali Nomor 2 Tahun 1988 tentang Lembaga Perkreditan Desa. LPD merupakan salah satu lembaga yang berada di tataran Desa Adat. Eksistensinya selama ini telah terbukti dan sangat dirasakan manfaatnya oleh krama Desa Adat. Krama adalah kelompok masyarakat yang berada di suatu Desa Adat. LPD tidak hanya bermanfaat sesuai fungsinya saja, namun juga menciptakan lapangan kerja (Kurniasari, 2007). Kedudukan LPD sebagai lembaga perkreditan di desa telah diakui keberadaannya berdasarkan hukum adat. Pengaturan LPD ini wajib dituangkan dalam awig-awig pada masing-masing Desa Adat. Pembentukan LPD didorong karena menguatnya kebutuhan keuangan desa pakraman dalam menyelenggarakan berbagai fungsi 
peradaban yang berat dan tidak pernah dikerjakan oleh lembaga keuangan umum. Peradaban budaya Bali yang menjadi landasan LPD menjadikan karakteristik khusus LPD bersifat sosial, komunal, religius (tidak hanya tanggung jawab secara fisik atau skala namun juga secara nonfisik atau niskala (Jayanthi et al., 2017).

Konsep hukum di Bali pada prinsipnya mengajarkan kepada warganya untuk menjalankan kewajibannya sebagai Krama Desa Adat, yakni melaksanakan ayahan desa (tugas-tugas krama desa) serta tunduk dan taat terhadap peraturan yang berlaku bagi Desa Adat (awig-awig). Krama Desa Adat memiliki kewajiban untuk menjunjung tinggi nama baik Desa Adat-nya yang berlandaskan kejujuran. Kejujuran inilah yang kemudian menjadi landasan pula bagi LPD dalam memberikan pelayanan jasa keuangan bagi Krama Desa Adat. Krama Desa Adat di Bali sangat patuh pada peraturan adatnya, mereka cenderung lebih takut pada sanksi adat dibanding dengan sanksi hukum nasional apabila melakukan pelanggaran adat. Bagi mereka, diasingkan oleh Desa Adat adalah hal terburuk yang harus dihindari. Oleh sebab itu dalam kehidupan sehari-hari mereka sangat berhati-hati, termasuk dalam menjalankan aktivitas ekonominya. LPD dikelola oleh Bendesa Adat yaitu pemangku tertinggi di Desa Adat yang mengetuai Kelian-Kelihan Banjar dalam suatu lingkungan adat. LPD memiliki pengurus yang ditunjuk berdasarkan hasil paruman (musyawarah) Desa Adat. Pengurus LPD adalah warga yang berasal dari tiap Banjar yang berada dalam satu Desa Adat, dan memiliki Badan Pengawas LPD Desa Adat yang terdiri dari seluruh Kelian Banjar di Desa Adat yang bersangkutan.

Kedudukan Desa Adat dalam perkembangan dan keberadaan LPD sangat strategis dan penuh dengan pertimbangan, yaitu:

a. Desa Adat merupakan lembaga tradisional yang telah megakar dan dihormati oleh masyarakat adat di Bali.

b. Desa Adat telah memiliki peraturan-peraturan yang telah disepakati dan dipatuhi secara tertulis maupun tidak tertulis

c. Desa Adat merupakan suatu kelompok yang didasarkan pada geografis dan berdasarkan interaksi sosial yang terjadi sehari-hari menyebabkan timbulnya rasa kesatuan dan kerjasama alamiah sebagai wujud gotong-royong yang terjalin erat.

d. Desa Adat memiliki kewajiban dan beban tanggungjawab yang cukup besar bila dibandingkan dengan hak yang dimilikinya dibandingkan bantuan yang diperoleh dari pihak pemerintah daerah dan pusat

Berdasarkan tinjauan umum pengurus LPD pengelolaan, adanya Desa Adat tersebut untuk menunjang lajunya perekonomian pedesaan yang dalam ini LPD sangat vital keberadaannya.

Pemerintah Daerah Tingkat I Bali membuat Peraturan Daerah Nomor 3 tahun 2017 tentang Lembaga Perkreditan Desa menyebutkan bahwa bidang usaha LPD meliputi :

a. menerima/menghimpun dana dari Krama Desa dalam bentuk dhana sepelan dan dhana sesepelan;

b. memberikan pinjaman kepada Krama Desa dan Desa;

c. LPD dapat memberikan pinjaman kepada Krama Desa lain dengan syarat ada kerjasama antar Desa.

d. Kerjasama antar Desa sebagaimana dimaksud huruf c diatur lebih lanjut dengan Peraturan Gubernur.

e. menerima pinjaman dari lembaga-lembaga keuangan maksimum sebesar $100 \%$ (seratus persen) dari jumlah modal, termasuk cadangan dan laba ditahan, kecuali batasan lain dalam jumlah pinjaman atau dukungan/bantuan dana. 
f. menyimpan kelebihan likuiditasnya pada Bank yang ditunjuk dengan imbalan bunga bersaing dan pelayanan yang memadai.

Saat ini keberadaan LPD di Bali berjumlah sekitar 1.433 LPD dari total 1.485 Desa Adat di Bali yang lebih banyak melayani pinjaman bagi masyarakat desa untuk berbagai keperluan (Setiawan, 2018). Hal ini membuktikan bahwa hampir 90\% Desa Adat yang ada di Bali memiliki LPD di desanya. Namun seperti yang telah diterbitkan oleh Tribun Bali, dari sekitar 1.434 Lembaga Perkreditan Desa (LPD) yang telah tersebar di seluruh Bali, pendapatan operasionalnya telah mencapai hampir di atas Rp. 2 Miliar sehingga memiliki resiko yang sangat besar terhadap keamanan tata kelola keuangannya. Data yang didapatkan dari Pansus LPD pada tahun 2017, sekitar 158 LPD di Bali tidak beroperasi lagi atau bangkrut (Parta, 2017). Hal ini menjadi masalah serius yang harus menjadi titik fokus oleh Lembaga Perkreditan Desa (LPD) karena terkait penyelamatan dana nasabah. Adanya otonomi yang diberikan oleh Desa Adat untuk pengelolaan LPD menimbulkan kecenderungan lembaga ini menganggap bukan bagian dari Desa Adat. Sehingga timbul polemik dari pengelolaan LPD tersebut, seperti lamanya masa jabatan yang diemban tak sesuai dengan peraturan yang ada, kredit fiktif yang digunakan oleh oknum tak bertanggung jawab. Serta timbulnya praktik-praktik korupsi yang kasusnya telah terjadi di LPD Kapal. Tertulis dalam Tribun Bali, sebanyak 5 kolektor divonis hukuman penjara karena telah melakukan tindak pidana korupsi (Candra, 2019).

Selain terjadinya tindak pidana korupsi yang dilakukan baik itu Pengurus dan pengelola LPD masih banyak terjadinya sengketa. Sengketa yang dilakukan oleh Pengurus dan pengelola LPD menimbulkan konflik kepentingan baik antara pengurus dengan karma adat atau antar pengurus dan pengelola baik dalam tugas dan fungsi kewenangannya. Sengketa permasalahan adat di desa dalam ruang lingkup LPD baik itu terindikasi yang menimbulkan kerugian desa atau pun pelanggaran Peraturan Perundang Undangan yang berlaku seringkali sengketa tersebut diselesaikan melalui hukum Nasional dibandingkan dengan hukum adat yang berlaku di suatu wilayah LPD. Di mana tujuan dari adanya hukum adalah untuk mencegah terjadinya pelanggaran ataupun sengketa.

Pelanggaran ataupun sengketa yang dilakukan oleh pengurus LPD dikarenakan sistem tata kelola masih bersifat absurd dan tidak sesuai dengan sistem ekonomi modern. Sistem tata kelola yang dilakukan LPD masih berdasarkan atas peraturan desa setempat (awig-awig). Di mana Bendesa Adat yang dipilih oleh Masyarakat Adat (Krama Adat) di suatu wilayah selain sebagai penanggung jawab, Bendesa Adat sebagai Pengawas LPD. Hal ini yang menjadikan kekuasaan Bendesa Adat memiliki kewenangan yang luas. Keyakinan Bendesa Adat akan menjadikan adanya konflik kepentingan (conflict of interest) dalam mengambil keputusan maupun kebijakan.

Pengambilan keputusan ataupun kebijakan yang dilakukan oleh Bendesa Adat harus sesuai dengan good governance dan high risk dalam sistem tata kelola jasa keuangan yang sehat. Sebagai ujung tombak dalam peningkatan kesejahteraan suatu Desa dan peningkatan kualitas manajemen jasa keuangan yang sehat Bendesa Adat wajib mengedepankan model tata kelola LPD yang saat ini masih bersifat konvensional menjadi terintegrasi. Terintegrasian tata kelola LPD harus mengedepankan asas akuntabilitas di mana pengawasan LPD secara internal patut dikelola oleh seseorang yang memiliki keahlian di dalam struktur kepengurusan Desa Adat.

Berdasarkan uraian tersebut di atas maka penulis tertarik untuk meneliti tentang peranan Desa Adat dalam melakukan pengelolaan LPD di Bali sehingga dapat mewujudkan tata kelola LPD yang bersih, transparan dan kredibel serta mampu menyelesaikan sengketa-sengketa yang muncul 
dalam pengelolaan lembaga tersebut. Untuk itu penulis mengambil judul "Peranan Desa Adat Dalam Tata Kelola Lembaga Perkreditan Desa (LPD) di Bali”.

\section{Rumusan Masalah}

Berdasarkan rumusan masalah di atas, maka dirumuskan beberapa permasalahan sebagai berikut Bagaimanakah peran Desa Adat di Bali dalam melakukan pengawasan terhadap pengelolaan Lembaga Perkreditan Desa (LPD)?

\section{METODE PENELITIAN \\ Sifat Penelitian}

Penelitian ini merupakan perpaduan antara penelitian hukum normatif dan penelitian hukum empiris. Bahan penelitian yang akan digunakan dalam penelitian ini meliputi data sekunder maupun data primer. Data sekunder adalah data yang berasal dari bahan-bahan kepustakaan, sedangkan data primer merupakan data yang diperoleh secara langsung dari subyek penelitian. Melalui penelitian kepustakaan kami mendapatkan data dan bahan hukum data sekunder. Data yang diperoleh dalam penelitian kepustakaan adalah data sekunder berupa kaedah atau norm asasasas hukum, kaedah-kaedah hukum dan sistimatik hukum. Sedangkan bahan hukum data sekunder dalam penelitian ini diperoleh dari bahan-bahan pustaka yang berhubungan dengan permasalahan, yang terdapat antara lain di dalam bahan hukum primer, bahan hukum sekunder, serta bahan hukum tersier. Cara pengumpulan data dalam penelitian kepustakaan ini adalah dengan merujuk kepada bahan-bahan yang didokumentasikan (Kumar, 1999). Alat yang dipergunakan dalam penelitian kepustakaan adalah studi dokumen. Dalam penelitian lapangan, data yang diperoleh dalam penelitian lapangan adalah data primer yang diperoleh secara langsung dari sampel atau subyek penelitian. Penelitian ini dilakukan di Lembaga Perkreditan Desa di Bali. Sampel atau subjek penelitian dalam penelitian lapangan adalah Ketua atau subjek yang memiliki kewenangan di Lembaga Perkreditan Desa di Bali. Metode pengambilan sampel yaitu purposive sampling.

\section{Jenis dan Teknik Pengumpulan Data}

Penelitian ini dilakukan dengan menggunakan berbagai pendekatan yang sesuai dengan objek kajian yang akan diteliti. Pendekatan yang digunakan adalah dengan sosiologis, yaitu penelitian berupa studi-studi empiris dan undang-undang. Jenis data yang digunakan antara lain: Pertama data sekunder, yang dikumpulkan melalui dokumen hukum yang ditelusuri. Kedua, data primer yang diambil langsung melalui studi lapangan dengan menggunakan teknik observasi dan wawancara mendalam. Cara pengumpulan data dalam penelitian lapangan ini yaitu dengan cara wawancara (Soerjono, 1981) dengan sampel/subjek peneliti (Arikunto, 1993). Alat pengumpulan data yang digunakan dalam penelitian ini adalah pedoman wawancara.

\section{HASIL DAN PEMBAHASAN}

\section{Hasil}

Bali adalah salah satu provinsi di Indonesia yang terkenal dengan kebudayaannya, salah satu keunikan di Bali adalah eksistensi dari desa pakraman dan desa. Lingkup desa pakraman tidak terbatas pada peran-peran sosial budaya dan keagamaan, melainkan juga ekonomi dan pelayanan umum yang umumnya berasal dari pemerintah. Melihat beratnya beban yang dipikul oleh desa pakraman, tentunya terbesit seberapa besar dana yang harus dikeluarkan oleh desa pakraman, tetapi ironisnya pembiayaan desa pakraman berada diluar kebijakan pembiayaan pemerintah. Kebijakan pembiayaan pemerintah hanya terbatas sampai desa saja, sedangkan desa pakraman juga memerlukan biaya yang tidak sedikit. Karena itu desa pakraman dituntut untuk memiliki tata kelola perekonomian mandiri, maka pada tahun 1984 pemerintah Bali mencetuskan pendirian Lembaga Perkreditan Desa di seluruh desa pakraman di Bali. Pada tahun 1984 dengan Surat 
Keputusan (SK) Gubernur No. 972 Tahun 1984 tentang Pendirian Lembaga Perkreditan Desa di Provinsi Daerah Tingkat I Bali. proyek pendirian LPD mulai dilakukan dan keberadaan LPD diatur di bawah Peraturan Daerah (PERDA) yakni Peraturan Daerah Provinsi Bali Nomor 8 Tahun 2002 Tentang Lembaga Perkreditan Desa (LPD), yang kini telah diganti menjadi Peraturan Daerah Provinsi Bali Nomor 3 Tahun 2007. Perda tersebut mengatur mengenai syarat-syarat pendirian LPD.

LPD sebagai suatu lembaga yang didirikan khusus untuk kepentingan demi mensejahterakan masyarakat desa pakraman, dalam kegiatannya hanya melayani masyarakat desa pakraman saja, LPD tidak melayani masyarakat di luar dari wilayah desa pakraman tempat LPD tersebut beroperasi. Karena itu LPD dikatakan sebagai lembaga keuangan yang memiliki sifat khusus. Pendirian LPD yang serentak diseluruh desa pakraman di Bali mulai memberikan hasil dalam meningkatkan perekonomian desa pakraman. Permasalah dalam LPD mulai muncul Sejak tahun diberlakukannya Undang-Undang Nomor 7 Tahun 1992 Tentang Perbankan, Keberadaan LPD mulai dipermasalahkan oleh Bank Indonesia (BI). BI berpendapat bahwa LPD melakukan kegiatan selayaknya Bank dan harus mentaati aturan mengenai perbankan. Untuk mempertegas BI juga menggunakan Undang-undang No. 7 Tahun 1992 Tentang Perbankan, yang memberikan status sebagai Bank Perkreditan Rakyat kepada LPD. Pada Kenyataannya argumentasi mengenai LPD melakukan kegiatan perbankan itu memang benar adanya, tapi dilihat dari latar belakang LPD bukanlah bank dan tidak dapat dipersamakan dengan bank. Pemerintah seakan tanpa hentihentinya mengusik keberadaan LPD di Bali. Pada 7 September 2009 Menteri Keuangan bersamasama dengan Menteri Dalam Negeri, Menteri Koperasi dan UMKM, dan Gubernur Bank Indonesia kembali menerbitkan Surat Keputusan Bersama Nomor 351.1/KMK.010/2009, Nomor 900-639A Tahun 2009, Nomor 01/SKB/M.KUKM/IX/2009 dan Nomor 11/43A/KEP.GB1/2009 Tentang Strategi Pengembangan Lembaga Keuangan Mikro. Diktum pertama keputusan tersebut memasukan LPD sebagai Lembaga Keuangan Mikro. Keberadaan LPD di masyarakat Desa Pakraman telah banyak mengalami peningkatan yang pesat. Lembaga keuangan LPD tersebut mampu meningkatkan potensi masyarakat Desa Pakraman, dan membantu masyarakat desa pakraman dalam kehidupannya didalam masyarakat Desa Pakraman. Sebagai contoh cara LPD dapat meringankan beban masyarakat Desa Pakraman, dapat kita lihat pada Desa Pakraman Kedonganan.

Misalnya, tradisi ngaben yang dianggap sebagai kewajiban personal umat Hindu membutuhkan biaya yang cukup besar. Jika kewajiban ini tidak ditunaikan, bisa berkembang menjadi masalah komunitas, bukan lagi masalah personal umat hindu. Disinilah keberadaan LPD sebagai lembaga keuangan masyarakat komunitas memberikan peranan besar dengan menyelenggarakan ngaben massal gratis. Peran LPD dalam membantu masyarakat Desa Pakraman juga termasuk dalam memberikan dana untuk membangun pura dan pelaksanaan upacara, yang sebelumnya dilakukan dengan dana pribadi masyarakat Desa Pakraman. LPD juga memberikan beasiswa berupa pendidikan kepada siswa yang berprestasi sehingga dapat melanjutkan pendidikannya ke jenjang yang lebih tinggi.

\section{Pembahasan}

Sebelum tahun 2019, Lembaga Perkreditan Desa yang selanjutnya disingkat dengan LPD yaitu salah satu lembaga yang dibentuk oleh Desa Pakraman yang berfungsi menjalankan dan mengelola sistem keuangan desa serta berupaya dalam memajukan kesejahteraan masyarakat desa dan memenuhi kepentingan masyarakat Desa Adat Pakraman itu sendiri. Pembentukan LPD didasari oleh adanya warisan budaya berupa Desa Pakraman yang merupakan suatu bentuk/wadah sistem pemerintahan tingkat desa yang terdiri dari ikatan kekeluargaan yang dalam Peraturan Daerah 
Provinsi Bali Nomor 3 Tahun 2017 diaturnya. Tetapi pada tahun 2019, pemerintah membentuk PerDa Provinsi Bali Nomor 4 Tahun 2019 tentang Desa Adat di Bali yang menyatakan bahwa adanya pergantian istilah Desa Pakraman menjadi Desa Adat.

Desa Adat adalah kesatuan masyarakat hukum adat di Bali yang memiliki wilayah, kedudukan, susunan asli, hak-hak tradisional, hak kekayaan sendiri, tradisi, tata krama pergaulan hidup masyarakat secara turun temurun dalam ikatan tempat suci serta memiliki hak otonomi. Sehingga semua istilah yang menggunakan Desa Pakraman diganti menjadi Desa Adat. Munculnya UndangUndang Nomor 1 Tahun 2013 tentang Lembaga Keuangan Mikro yang memisahkan kestatusan LPD dalam Pasal 39 ayat (3) bahwa adanya penghapusan status terhadap LPD sebagai Lembaga keuangan Mikro, di mana LPD diberikan suatu suara sah secara legal sebagai lembaga keuangan warga Desa Adat berdasarkan peran yang dimunculkannya terhadap masyarakat Desa Adat tersebut serta pengakuan dan pemberian kekhususan sehingga status dan kedudukan Lembaga Perkreditan Desa adalah sebuah lembaga yang bernaung pada Desa Adat dengan kata lain LPD hanya dimiliki oleh Desa Adat dan mengikuti segala aturan yang dibuat oleh Desa Adat.

Lembaga perkreditan Desa atau disingkat sebagai LPD merupakan badan usaha keuangan milik desa yang melaksanakan kegiatan usaha di lingkungan desa dan krama desa. LPD sebagai lembaga keuangan yang melakukan kegiatan penghimpunan dan penyaluran dana masyarakat beroperasi pada suatu wilayah administrasi Desa Adat dengan dasar kekeluargaan antara warga desa. Modal LPD salah satunya berasal dari swadaya masyarakat atau urunan karma desa. Sebelum direncanakan dan dibangunnya LPD di Provinsi Bali, setiap Desa Adat sudah memiliki sekehe/perkumpulan yang umumnya sekehe tersebut juga punya dana atau uang kas yang disebarkan pada anggota.

Sebelum dikeluarkannya Undang-Undang Nomor 1 Tahun 2013 tentang Lembaga Keuangan Mikro untuk mengatur LPD, pemerintah telah membentuk Undang-Undang Nomor 7 Tahun 1992 jo. Undang-Undang Nomor 10 Tahun 1998 tentang Perbankan di mana disebutkan pada Pasal 58 bahwa Lembaga Perkreditan Desa diberikan status oleh pemerintah dengan Bank Perkreditan Rakyat (BPR) sehingga pengelolaan sistem di dalam LPD mengikuti semuanya aturan yang sama dengan BPR, namun hal tersebut tidaklah sesuai dengan visi dan misi LPD. Dapat diketahui bahwa LPD "visi dan misi LPD haruslah menjadi lembaga keuangan adat yang sehat, tangguh, dan bermanfaat bagi kehidupan krama dan Desa Adat yang berlandaskan Tri Hita Karana" dan berbasis adat dan budaya serta diharapkan mampu meningkatkan kualitas Sumber Daya Manusia masyarakat Desa Adat setempat secara individu ataupun organisasi demi berkembang suatu desa tersebut. Hal tersebut dapat dilihat bahwa status dan kedudukan LPD dan BPR sangatlah berbeda. Selain itu, landasan bekerjanya LPD yakni hanya sesuai aturan awig-awig Desa Adat sedangkan BPR berlandas pada Undang-Undang Nomor 10 Tahun 1998 tentang Perbankan, serta anggota pengurus LPD dipilih dari "Paruman, Bendesa atau Prajuru Adat sedangkan pengurus BPR dipilih melalui Rapat Umum Pemegang Saham, Komisaris dan Direksi. Serta jangkauan ruang lingkup LPD berbeda dengan BPR, LPD hanya menjangkau sebatas Desa Adat di mana dibentuknya LPD tersebut lain halnya BPR yang bisa menjangkau seluruh wilayah "Negara Kesatuan Republik Indonesia".

"Pada Pasal 11 angka 10 Peraturan Daerah Nomor 8 Tahun 2002 tentang Lembaga Perkreditan Desa, dinyatakan bahwa LPD adalah ,merupakan badan usaha keuangan milik Desa Pakraman yang mengacu pada Undang-Undang Nomor 32 Tahun 2004 tentang Pemerintahan Daerah yang mana mengenai Badan Usaha Milik Desa (BUMDes) pada Pasal 213 yang menyatakan" bahwa, "Desa dapat mendirikan badan usaha milik desa sesuai dengan kebutuhan perundang-undangan". 
Dari pernyataan tersebut sesungguhnya apabila dilihat dari tujuan LPD sendiri sangatlah berbeda dengan tujuan BUMDes. Untuk itu pemerintah membentuk "Peraturan Daerah Provinsi Bali Nomor 4 Tahun 2012 tentang Perubahan Kedua Atas Peraturan Daerah Provinsi Bali Nomor 8 Tahun 2002 tentang Lembaga Perkreditan Desa". Dalam peraturan yang baru ini, pemerintah merubah pengertian Lembaga Perkreditan Desa adalah lembaga keuangan dimiliki Desa Pakraman yang hanya mendominasi tentang tata cara kelola Lembaga Perkreditan Desa saja. Untuk itu pemerintah kembali lagi merevisi peraturan daerah mengenai LPD, lagi ke dalam "Peraturan Gubernur Nomor 11 tahun 2013 tentang Petunjuk Pelaksanaan Peraturan Daerah Provinsi Bali Nomor 8 Tahun 2002 tentang Lembaga Perkreditan Desa (LPD)" di mana menuliskan bahwa tata cara pengelolaan dan bidang keuangan LPD sangatlah sama dengan BPR.

"Dengan dikeluarkannya Perda Provinsi Bali Nomor 8 tahun 2002 tentang Lembaga Perkreditan Desa, pada tahun 2013 dibentuklah Undang-Undang Nomor 1 tahun 2013 tentang Lembaga Keuangan Mikro yang pada Pasal 39 ayat (3) menyatakan bahwa" "Lembaga Perkreditan Desa dan Lumbung Pitih Nagari serta lembaga sejenis yang telah ada sebelum undang - undang ini berlaku, dinyatakan diakui keberadaannya berdasarkan hukum adat dan tidak tunduk pada undang - undang ini". Dalam pernyataan tersebut diketahui bahwa adanya perintah dari pemerintah pusat untuk melepaskan perihal segala urusan yang menyangkut LPD baik dalam segi pengelolaan dan perbankannya kepada Desa Adat di mana LPD tersebut dibentuk, sehingga dapat dikatakan bahwa status LPD yaitu merupakan lembaga independen milik Desa Adat. Hal tersebut juga mengacu pada asas hukum Lex Specialis Derogat Legi Generalis yang berarti bahwa aturan hukum khusus akan mengesampingkan aturan hukum yang bersifat umum.

"Pada awalnya LPD di prakarsai oleh Gubernur Bali Prof. Ida Bagus Mantra pada tahun 1985 setelah mengikuti seminar tentang Lembaga Keuangan Desa atau Badan Kredit Desa di semarang. Maka akhirnya dibentuklah Peraturan Daerah Tingkat 1 Bali Nomor 2 Tahun 1988 tentang LPD. Pada tahun 1997 ditetapkannya PerDa Tingkat 1 Bali Nomor 199 Tahun 1997 tentang pembentukan susunan Keanggotaan Badan Pembina LPD sebagai acuan kinerja LPD. Lalu pada tahun 2017 di bentuklah Peraturan Daerah Provinsi Bali Nomor 3 Tahun 2017 yang dalam Pasal 1 angka 5 berbunyi tentang Lembaga Perkreditan Desa menyatakan Desa Pakraman yang selanjutnya disebut Desa, adalah kesatuan masyarakat hukum adat di Provinsi Bali yang mempunyai satu kesatuan tradisi dan tata krama pergaulan hidup masyarakat umat Hindu secara turun temurun dalam ikatan Kahyangan Tiga atau Kahyangan Desa yang mempunyai wilayah tertentu dan harta kekayaan sendiri serta berhak mengurus rumah tangganya sendiri” Tetapi pada tahun 2019, pemerintah mengesahkan PerDa Provinsi Bali Nomor 4 Tahun 2019 tentang Desa Adat di Bali yang menyatakan bahwa adanya pergantian istilah Desa Pakraman menjadi Desa Adat, sehingga semua istilah yang menggunakan Desa Pakraman diganti menjadi Desa Adat. Sehingga dapat diketahui bahwa LPD dibentuk dan di sah kan hanya untuk dimiliki oleh Desa Adat karena seluruh pengaturan LPD hanya berpusat dan berpedoman pada awig-awig atau aturanaturan khusus yang dimiliki suatu Desa Adat setempat. Untuk itu tujuan serta peran yang sebagaimana diatur untuk LPD menjadikan LPD sebagai Institusi Keuangan Desa Adat. Adapun tujuan LPD terdapat dalam Pasal 3 Peraturan Daerah Provinsi Bali Nomor 3 Tahun 2017 tentang Lembaga Perkreditan Desa adalah LPD melaksanakan kegiatan operasional usaha di lingkungan Desa dan untuk Krama Desa. Adapun fungsi LPD tertuang dalam Pasal 3 PerDa Provinsi Bali Nomor 2 Tahun 1988 di mana LPD berfungsi sebagai wadah kekayaan masyarakat desa dan peningkat taraf hidup karma desa. Serta peran-peran tersebut terdapat dalam Pasal 7 Peraturan Daerah Provinsi Bali Nomor 3 Tahun 2017 tentang Lembaga Perkreditan Desa, dinyatakan bidang usaha LPD mencakup, Menerima atau menghimpun dana dari Krama Desa dalam bentuk dhana sepelan dan dhana sesepela, Memberikan pinjaman kepada Krama Desa dan Desa; Lembaga 
Perkreditan Desa dapat memberikan pinjaman kepada Krama Desa lain dengan syarat ada kerjasama antar Desa yang sesuai dengan peraturan Gubernur, Menerima pinjaman dari lembagalembaga keuangan maksimum sebesar $100 \%$ (seratus persen) dari jumlah modal, termasuk cadangan dan laba ditahan, kecuali batasan lain dalam jumlah pinjaman atau dukungan/bantuan dana Karena hal-hal tersebut di atas, maka Lembaga Perkreditan Desa dapat dikatakan sebagai Institusi Keuangan Desa Adat yang sah dimata hukum.

\section{KESIMPULAN DAN SARAN}

Berdasarkan pemaparan yang tersebut di atas, dapat disimpulkan bahwa Peran Desa Adat di Bali malam Melakukan pengawasan terhadap Pengelolaan Lembaga Perkreditan Desa (LPD) sesuai dengan Status LPD apabila ditinjau dari Undang-Undang Nomor 1 Tahun 2013 tentang Lembaga Keuangan Mikro, telah jelas bahwa LPD merupakan lembaga yang tunduk di bawah naungan Desa Adat yang segala aturan baik tugas maupun fungsinya mengikuti aturan Desa Adat yang tertulis dalam awig-awig Desa Adat yang ditegaskan dalam Pasal 39 ayat (3) UU LKM dan PerDa Provinsi Bali Nomor 3 tahun 2017 tentang LPD yang mengotonomikan segala urusan LPD kepada ${ }^{\text {ee }}$ Desa Adat yang diperkuat dengan PerDa Provinsi Bali Nomor 4 Tahun 2019 tentang Desa Adat di Bali. Sehingga kesenjangan norma terhadap pendirian LKM khususnya LPD telah jelas bahwa LPD dalam pendiriannya mengikuti segala aturan yang ditetapkan oleh Desa Adat masing-masing wilayah desa di mana LPD tersebut didirikan. Pun dalam hal ini LPD dapat dikatakan sebagai institusi keuangan desa yang dilihat dalam tujuan dan peran LPD yang tertuang pada Pasal 3 dan Pasal 7 PerDa Provinsi Bali Nomor 3 Tahun 2017 dan fungsi LPD yang didalamnya mencakup tujuan didirikannya LPD serta segala jenis bidang usaha LPD yang diizinkan beroperasi serta menjadi bukti bahwa LPD telah diatur dalam Peraturan Daerah sehingga telah jelas diakui sebagai sebuah institusi keuangan Desa Adat.

Pun dalam hal ini dapat diketahui secara jelas bahwa Undang-Undang Nomor 1 Tahun 2013 tentang Lembaga Keuangan Mikro menjadikan LPD bergerak hanya berdasar pada awig-awig Desa Adat, tetapi krama Desa Adat merupakan bagian dari Masyarakat Negara Kesatuan Republik Indonesia yang seharusnya mengikuti aturan hukum yang berlaku di Indonesia. Oleh karena itu walaupun Undang-Undang Nomor 1 tahun 2013 tentang Lembaga Keuangan Mikro membebaskan aturan LPD kepada Desa Pakraman, hendaknya awig-awig atau aturan Desa Pakraman yang dibuat untuk LPD sesuai dengan hukum yang berlaku di Indonesia. Pun dalam hal dengan melihat tujuan, fungsi dan peran LPD tersebut sebagai sebuah institusi keuangan Desa Adat, tetaplah hendaknya Krama Desa juga melakukan pengawasan terhadap jalannya operasi LPD sehingga tujuan dan peran tersebut dapat terselesaikan dengan baik

Ucapan Terima Kasih (Acknowledgement)

Kami mengucapkan terimakasih kepada Lembaga Penelitian dan Pengabdian kepada Masyarakat (LPPM) Universitas Tarumanagara dan Lembaga Perkreditan Desa di Bali.

\section{REFERENSI}

Amrani, H. (2001). Analisis ekonomi terhadap hukum sebagai upaya peningkatan peranan hukum dalam pembangunan. Jurnal Hukum, 8(18).

Arikunto, S. (1993). Prosedur penelitian suatu pendekatan praktek (2nd ed.). Rineka Cipta.

Setiawan, P. (2018, November 22). Total aset Rp. 215 Triliun, LPD di Bali perlu penguatan lembaga.

Beritabali.com. https://news.beritabali.com/read/2018/11/22/201811220014/total-aset-rp-21-5-triliun-lpddi-bali-perlu-penguatan-lembaga

Cooter, R., \& Uien, T. (2000). Lawand economics (3rd ed.). Addison Wisiey Longman Inc. 
Kelsen, H. (2006). General theory of law \& state. Transaction Publishers.

Kumar, R. (1999). Research methodology: A step-by-step guide for beginners. Addison Wedley Longman Australia Pty.

Kurniasari, T. W. (2007). Lembaga perkreditan desa dalam perspektif hukum: Sebuah lembaga keuangan adat hindu penggerak usaha sektor informal di Bali. Jurnal Masyarakat dan Budaya, 9(1).

Kurniasari, T. W. (2007). Lembaga perkreditan desa (LPD) dalam perspektif hukum: Sebuah lembaga keuangan adat hindu penggerak usaha sektor informal di Bali. Jurnal Masyarakat dan Budaya, 9.

Kriekhoff, V. J. L. (1997). Autonomic legislation sebagai sumber hukum formal dalam penelitian hukum. UI Press.

Putra, I. B. W. (2016). Teori hukum dengan orientasi kebijakan (policy oriented theory of law): Pemecahan problem konteks dalam proses legislasi Indonesia. Udayana University Press.

Posner, R. A. (1992). Economic analysis of law (4th ed.). Little Brown and Company.

Jayanthi, N. M. D., Wairocana, I. G. I. N., \& Wiryawan, I. W. (2017). Status dan kedudukan lembaga perkreditan desa (LPD) terkait pengikatan jaminan dengan berlakunya UndangUndang nomor 1 Tahun 2013 tentang Lembaga Keuangan Mikro. Acta Comitas: Jurnal Ilmiah Prodi Magister Kenoktariatan, 2(2).

Maria, S. W. (1989). Pedoman pembuatan usulan penelitian. PT. Gramedia.

McDougal, M. S. (1956). Law as process of decision: A policy oriented approach to legal study. Natural Law Forum. https://digitalcommons.law.yale.edu/cgi/viewcontent.cgi?article=3494\&context=fss_pape rs

Noah, S. M. (2002). Reka bentuk penyelidikan: Falsafah, teori dan praktis, sebuah buku mesra pengguna. Penerbit Universiti Putera Malaysia.

Sambas, L. (2016). Teori-teori hukum klasik dan kontemporer. Ghalia Indonesia.

Soekanto, S. (1981). Pengantar penelitian hukum (2nd ed.). Universitas Indonesia Press.

Soemitro, R. H. (1994). Metodologi penelitian hukum dan jurimetri. Ghalia Indonesia.

Parta, N.. (2017, April 29). 150 LPD di Bali dinyatakan bangkrut. Tribun Bali. https://balitribune.co.id/content/150-lpd-di-bali-dinyatakan-bangkrut

Candra, P. (2019, Agustus 21). Kasus korupsi LPD desa adat kapal, lima perempuan mantan kolektor dituntut berbeda. Tribun Bali. https://bali.tribunnews.com/2019/08/21/kasuskorupsi-lpd-desa-adat-kapal-lima-perempuan-mantan-kolektor-dituntut-berbeda

Widjaja, H. A. W. (2003). Pemerintahan desa. PT. Raja Grafindo Persada. 